\title{
Invasion impact is conditioned by initial vegetation states
}

\author{
L. Bakacsy \\ Department of Plant Biology, Institute of Biology, Faculty of Science and Informatics, University of Szeged, \\ H-6726 Szeged, Hungary.E-mail: bakacsy@bio.u-szeged.hu
}

Keywords: Asclepias syriaca, Beta diversity, Compositional diversity, Invasion, JNP-functions, Microcoenology, Sandy grassland vegetation, Spatial scale.

\begin{abstract}
Biological invasion is a crucial problem in the world because of its negative consequences for protected areas. The degradation stage of vegetation might affect the success of invasion. One of the most abundant and threatening invasive species is the common milkweed (Asclepias syriaca L.) which has invaded already 23 countries of Europe and in several habitat types its further spreading is promoted by climate change. Pannonian sand grassland is one of the most threatened habitat by common milkweed invasion. Therefore, invasion in sand grassland vegetation is an important issue. However, the effects of the invasive plant in the open sand grassland are rather controversial. In order to clarify the existing contradictory results, the study was carried out in a strictly protected area, near Fülöpháza (Hungary) in a reserve core area in a UNESCO biosphere reserve. Microcoenological study was applied to determinate the fine-scale community characteristics of non-invaded and invaded stands in natural and seminatural vegetation and data were processed by Juhász-Nagy's information theory models. Shannon diversity of species combinations (compositional diversity) which describes the ways of the coexistence of species, and the number of realized species combinations were used for measuring beta diversity. Differences between stands were analyzed by two-way ANOVA. The maximum compositional diversity of species and main life-forms (annuals, perennials and cryptogams) did not differ significantly between the non-invaded and invaded stands. In contrast, significantly larger characteristic areas of compositional diversity were detected in the invaded stands. Based on these results, it could be concluded that diversity of species combinations did not change but those values have shifted to coarser scales in case of invaded stands. The direction of this change suggests a kind of impoverishment in the presence of Asclepias. Thus, it is worth mentioning from the invasion management point of view that protection of the habitats against disturbance is a more cost-effective and successful way than protection against the establishment or extirpation of invasive species, since disturbance facilitates the invasions throughout the impoverishment of the community.
\end{abstract}

Abbreviations: CD - Compositional (species combination) Diversity, CA - Characteristic Area, JNP-functions - JuhászNagy's functions, NRC - Number of Realized species Combinations .

Nomenclature: The study used the nomenclature for names of plant species and the life form categories by Raunkiaer as applied by Király (2009).

\section{Introduction}

Invasion in protected areas means serious problems for the biodiversity and functioning of ecosystems (Elton 1958, Sala et al. 2000, Weidenhamer and Callaway 2010, European Commission 2014). Disturbed vegetation units usually are not capable to resist against invasion (Alpert et al. 2000).

Common milkweed (Asclepias syriaca L.) is a tall perennial plant species, originated from North America. This species has characteristics that make it a noxious invasive species (e.g., fast growing, clonal spreading, and drought tolerance) (Bagi 2008, Tokarska-Guzik and Pisarczyk 2015, Kelemen et al. 2016). Despite the facts that common milkweed has invaded already 23 countries of Europe and further spread is promoted by climate change (Tokarska-Guzik and Pisarczyk 2015), very few studies have examined the effects of its invasion (Bagi and Szilágyi 1995, Kelemen et al. 2016, Szitár et al. 2014, 2016, 2018). The species has recently been added to the List of Invasive Alien Species of Union Concern in 2017 (European Commissions 2017). In Hungary, common milkweed is one of the most abundant invasive species which has the largest cover in sandy old-fields (Török et al. 2003, Bagi 2008, Csecserits et al. 2011, Kelemen et al. 2016) due to some damaging processes, e.g., wildfire (Mojzes and Kalapos 2015, Szatmári et al. 2016) or previous uncontrolled land use (Csontos et al. 2009, Albert et al. 2014). Several studies have shown that disturbed vegetation colonized by $A$. syriaca could promote the spreading of this plant efficiently into surrounding seminatural communities (Csontos et al. 2009, Csecserics et al. 2011, Albert et al. 2014, Szitár et al. 2014). Few studies have been reported controversial results about its effects on different vegetation types. First, milkweed did not influence the establishment of the dominant grasses following wildfire in alien pine plantations (Szitár et al. 2014, 2016). Moreover, a recent study has shown that Asclepias could have nurse effects on the native grass establishment during early recovery in old-fields (Szitár et al 2018). Due to the deep roots, Asclepias is able to reach the unused water regimes of native species (Bagi 2008), so there is no competition for water storage or competition can be limited between these spe- 
cies (Szitár et al. 2016). Second, in the presence of Asclepias the development of target vegetation has been reported to be slowed down (Albert et al. 2014). The presence of common milkweed has a negative impact on the cover of native species in the late successional sandy grasslands (Kelemen et al. 2016) which can be explained by its shading and allelopathic effects (Kazinczi et al. 2004). Negative impacts on the native fauna (arthropods) were also reported by Gallé et al. (2015) and Somogyi et al. (2017). Therefore, the organization and dynamics of vegetation invaded by milkweed deserves special attention from the point of view of nature conservation. Our knowledge is limited about the background of Asclepias invasion due to the relatively low number of published studies related to the initial vegetation states. A microcenological study was carried out to inform about the characteristics of non-invaded and invaded stands of natural and seminatural vegetation at fine-scale.

Pannonian sand steppes or open sand steppes (Natura 2000 code: 6260) are of special importance for the European Union Habitat Directive (92/43/CEE). These dry, nutrientpoor, calcareous sand habitats are home to a large number of rare, endangered or endemic species (Tóth 1996, Lökös and Verseghy 2001, Molnár 2003, Molnár and Kun 2011, Fekete et al. 2014, Veres and Csintalan 2017) and they are very vulnerable to biological invasion (Botta-Dukát 2008). A possible reason of high invasibility of open sand grasslands is the former land use (and the related disturbances) in the past (Botta-Dukát 2008). There are several negative impacts of disturbance such as decrease of diversity altered by composition of species with increasing portion of annual plants and ecosystem functions (Kovács-Láng et al. 2000). The link between disturbance and plant invasion is also widely recognized (Hobbs 1989, Alpert et al. 2000, Hierro et al. 2006, Csecserits et al. 2011, Pyšek et al. 2012, Lembrechts et al. 2016, Pyšek et al. 2017).

For a better understanding of invasion processes, detailed studies on vegetation structure and transitions with specific attention to the initial conditions are necessary. Thus, besides the use of conventional methods, the changes of the number of species and the relationship between fine-scale spatial structure and vegetation dynamics have to be measured. These require a complex approach, such as microcoenological methods which are used in several previous studies (Juhász-Nagy 1980, Juhász-Nagy and Podani 1983, JuhászNagy 1993, Horváth and Makrai 2000, Kovács-Láng et al. 2000, Bartha 2008, Bartha et al. 2008, Bartha et al. 2011). Two commonly used functions of the model family of JuhászNagy: compositional diversity (CD) and the number of realized species combinations (NRC) are sensitive indicators of community composition and structure. In spite of that, they have been used only in few studies in which the interaction of the invasive species and the invaded community were examined (Szigetvári 2002, Szentes et al. 2012, Kun et al. 2014).

The basic hypothesis of the study is that invasion is associated with decreasing beta diversity, i.e., invasion is facilitated by the decreasing diversity. The application of the two information theory functions; namely, the diversity of species combinations and the number of realized species combinations inform us about beta diversity. According to the hypothesis, the values of the two functions are drastically reduced, while the characteristic areas of the two functions are shifted at coarser scales due to the decreasing beta diversity. Therefore, the maximum values and characteristic areas of non-invaded and invaded stands of natural and seminatural vegetation are compared. Furthermore, this study evaluated whether these differences are manifested in three main lifeform categories (annuals, perennials and cryptogams).

\section{Materials and methods}

The study was carried out in the strictly protected UNESCO biosphere reserve core area near Fülöpháza in

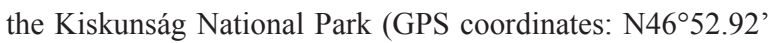
E0 $19^{\circ} 23.94^{\prime}$ ), Central Hungary (Fig. 1 and Table S1 in the Appendix).

The native habitat type of the study site is open sand grassland (which belongs to the Festucetum vaginatae association), but there are some closed sand grasslands, poplarjuniper shrublands and disturbed and transformed habitats as well. The latter ones (plantations, abandoned fields) play an important role in the invasion of the sites by Asclepias. The groundwater level is at a high depth (Zsákovics et al. 2007, 2009 ) and the mean annual precipitation varies between 565 mm and 535 mm (Tóth 1996, Kovács-Láng et al. 2000, Kun 2001, Bartha et al. 2011). The mean annual temperature is between $10.07{ }^{\circ} \mathrm{C}$ and $10.33{ }^{\circ} \mathrm{C}$ (Kovács-Láng et al. 2000, Bartha et al. 2011). The nutrient deficient, weak soil profile developed on calcareous sand (Várallyay 1993, Kovács-Láng et al. 2000). Nonetheless, the area has many floristic values, characterized by a rich lichen flora (e.g., Cladonia convoluta, Cladonia furcata, Cladonia magyarica, Cladonia rangiformis) (Lőkös and Verseghy 2001, Molnár and Kun 2011, Veres and Csintalan 2017) and some typical endemic plants, e.g., Festuca vaginata, Colchicum arenarium, Dianthus diutinus, Dianthus serotinus, Iris arenaria (Tóth 1996, Molnár 2003, Magyari et al. 2010, Molnár and Kun 2011, Rédei et al. 2014). The study area has been protected and abandoned since 1974, but it was used for grazing and military excersises before protection. It is important to note that there were also some agricultural activities (agricultural fields and farmsteads) in and around the sand dunes between the 1950's and 80's.

Five non-invaded (NI) (as control) and five invaded stand (I) pairs were examined by comparative microcoenological approaches. Vegetation sampling was performed from May to June, in 2015. Four (1-4) of the stands were located in oldfields as seminatural (SN) sites. (These stands were arable fields previously and have been abandoned since the 196070 's. They have been spontaneously recovering since then.) The fifth stand was located in the undisturbed sand dune area. It was probably never ploughed and was considered as a natural (reference) site (N) (Fig. 1). The non-invaded stands were designated only a few meters away from their invaded stand pairs to have as similar abiotic conditions and vegetation history as possible. Each individual stand was analyzed and interpreted 


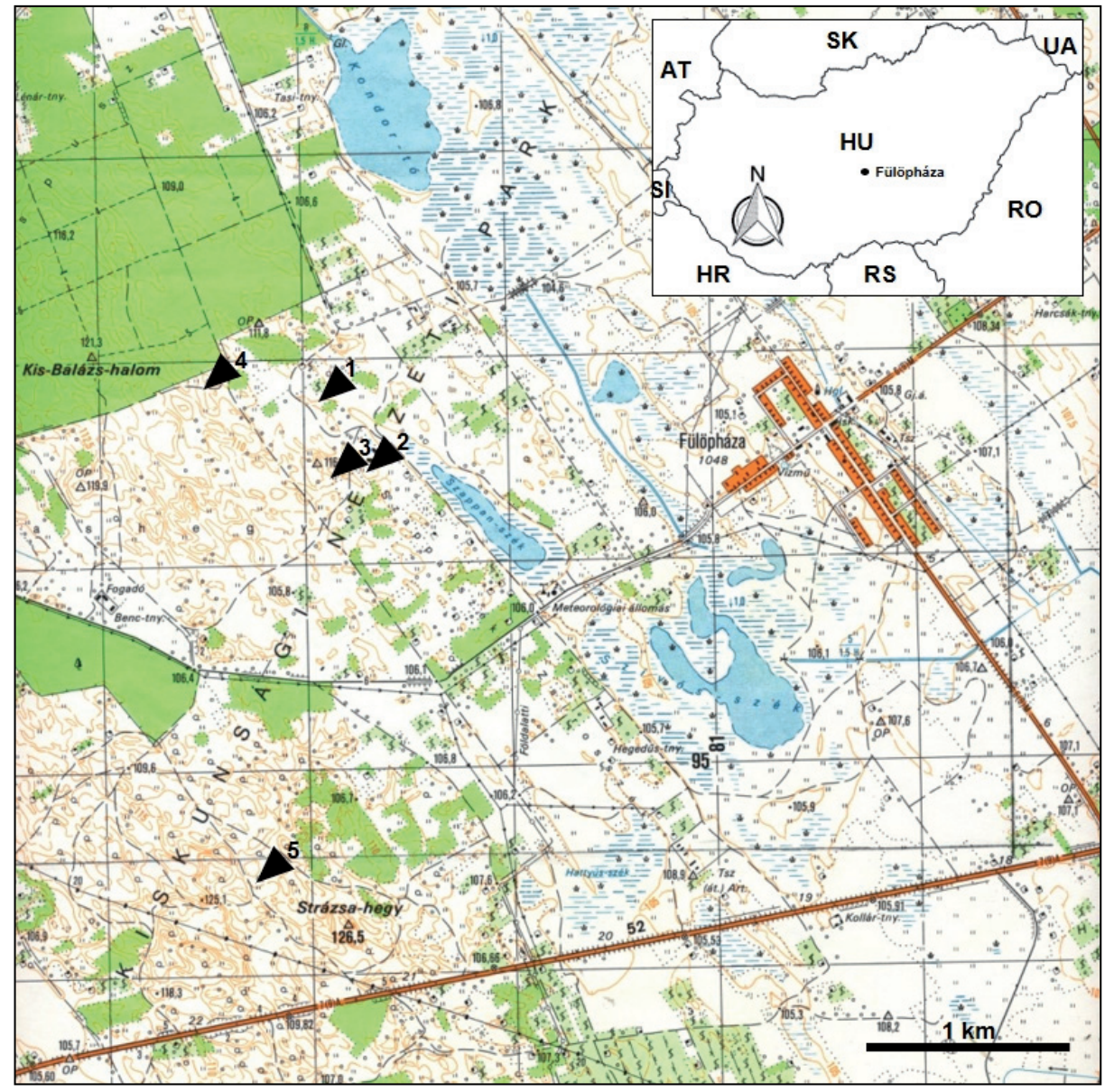

Figure 1. Map of the vegetation states examined in this study. The location of the study site in Hungary (Fülöpháza) is labeled by black arrows and their approximate positions of the stand-pairs are labeled by number 1-5. The four (14) of the stand-pairs are located on previous arable fields (seminatural vegetation), the fifth is located in the sand dune area (natural vegetation) (for finer classification of the stands cf. Table S4.).

in the contrast of its pair. Based on this design, we assume that differences in vegetation composition and patterns can be attributed to the effect of invasive species. The frequency of Asclepias and the other species in the five stands differed, as was determined from their presence. The selection criteria of individual stands were that they occur in homogeneous vegetation patches without larger visible disturbances large enough to place a $52 \mathrm{~m}$ long circular transect on them.

In sand grasslands, the following standard sampling procedure was used for microcoenological studies (Bartha and Kertész 1998, Szigetvári 2002, Bartha et al. 2008, Bartha et al. 2011, Szentes et al. 2012): The presence of plant species along $52 \mathrm{~m}$ long circular transects was recorded in each stand, every transect consisted of 1040 units of $5 \mathrm{~cm} \times 5 \mathrm{~cm}$ contiguous microquadrats.

From each transect, the relative total frequency and relative frequency of three main life-forms were determined. The first is based on the number of presences of species in microquadrats. The second is based on the number of presences of species with similar life-forms in microquadrats.

For data analysis, two Juhász-Nagy's information theory models were used (Juhász-Nagy 1980, Juhász-Nagy and Podani 1983), hereafter abbreviated as JNP-functions: compositional diversity $(\mathrm{CD})$ and the number of realized species combinations (NRC). The first function is the Shannon diversity of species combinations weighted by the frequency of species combinations (given in logarithmic units, bits), while the latter one (NRC) expresses only the number of realized combinations. In this study, the maximum values and the characteristic areas (CA) were used (CA is the maximum quadrat size where the particular function reaches its maximum (Campetella et al. 1999, Campetella and Canullo 2001)). Transformations of the characteristic areas of CD and $\mathrm{NRC}$ inform us about changing beta diversity and they very sensitively detect fine changes in the patterns of species coexistence during succession or degradation (cf. Juhász-Nagy and Podani 1983, Bartha et al. 2011, Szentes et al. 2012).

INFOTHEM 3.01 program was used for performing spatial series analyses, and calculating JNP-functions (Horváth 1998). Species with frequency under $2 \%$ were excluded from the data processing as the rare species can lead to misleading results (Tóthmérész and Erdei 1992, Addicott et al. 2018) (Table S3).

Asclepias was excluded from the model in all analyses of invaded stands, because we use this species as an independent ("driver") variable.

Based on previous studies (Virágh et al. 2008, Szentes et al. 2012), we assume that the rank of the stands ordered by decreasing maximum $\mathrm{CD}$ indicates the degree of disturbance (Virágh et al. 2008, Szentes et al. 2012) (where lower CD indicates larger disturbance, Table S4). After the first level (a priori) distinction between natural and seminatural stands, 
Table 1. The frequency of three major Raunkiaer life-form categories and invasive plants, and the species number. SN - seminatural sites (1-4), N - natural site (5), NI - non-invaded stands, I - invaded stands. Species with a frequency below $2 \%$ are not included in the analysis.

\begin{tabular}{|c|c|c|c|c|c|c|c|}
\hline Sites & Stands & Annual species & $\begin{array}{l}\text { Perennial species } \\
\text { (without Asclepias) }\end{array}$ & Cryptogams & Asclepias syriaca & Total & $\begin{array}{l}\text { Species } \\
\text { number }\end{array}$ \\
\hline \multirow[t]{2}{*}{$\mathrm{SN}$} & NI1 & $17.67 \%$ & $2.21 \%$ & $45.48 \%$ & $0 \%$ & $65.36 \%$ & 13 \\
\hline & I1 & $13.17 \%$ & $3.60 \%$ & $35.38 \%$ & $8.65 \%$ & $60.8 \%$ & 15 \\
\hline \multirow[t]{2}{*}{$\mathrm{SN}$} & NI2 & $15.09 \%$ & $10.96 \%$ & $30.12 \%$ & $0 \%$ & $56.17 \%$ & 9 \\
\hline & $\mathrm{I} 2$ & $10.36 \%$ & $6.17 \%$ & $76.00 \%$ & $7.30 \%$ & $99.83 \%$ & 11 \\
\hline \multirow[t]{2}{*}{$\mathrm{SN}$} & NI3 & $4.55 \%$ & $15.45 \%$ & $34.55 \%$ & $0 \%$ & $54.55 \%$ & 10 \\
\hline & I3 & $6.87 \%$ & $10.55 \%$ & $38.04 \%$ & $5.86 \%$ & $61.32 \%$ & 14 \\
\hline \multirow[t]{2}{*}{$\mathrm{SN}$} & NI4 & $18.63 \%$ & $2.78 \%$ & $37.50 \%$ & $0 \%$ & $58.91 \%$ & 10 \\
\hline & I4 & $13.00 \%$ & $6.10 \%$ & $52.35 \%$ & $8.26 \%$ & $79.71 \%$ & 9 \\
\hline \multirow[t]{2}{*}{$\mathrm{N}$} & NI5 & $5.40 \%$ & $8.49 \%$ & $43.14 \%$ & $0 \%$ & $57.03 \%$ & 11 \\
\hline & I5 & $7.01 \%$ & $13.36 \%$ & $34.51 \%$ & $10.86 \%$ & $65.74 \%$ & 7 \\
\hline \multirow[t]{2}{*}{ Average } & $\mathrm{N}$ & $12.26 \%$ & $7.97 \%$ & $38.15 \%$ & $0 \%$ & $58.40 \%$ & 10.6 \\
\hline & A & $10.08 \%$ & $7.95 \%$ & $47.33 \%$ & $8.18 \%$ & $73.62 \%$ & 11.2 \\
\hline
\end{tabular}

these rankings provide additional (a posteriori) assessment of degradation. This a posteriori ordering of stands (based on decreasing beta diversity) has an important role in this paper as we expected larger responses to invasion in more degraded stands (cf. main hypothesis).

JNP-functions of the three main Raunkiaer life-form categories (annuals, perennials and cryptogams) were also analyzed by the program in separate tests. The settings were the same as in the above mentioned basic analyses: randomization procedure, $2 \%$ species frequency threshold was used and the Asclepias was excluded from the model (in the case of perennials).

Two-way ANOVA was used for the comparisons (the maximum values and $\mathrm{CA}$ of the $\mathrm{CD}, \mathrm{NRC}$ and the maximum $\mathrm{CD}$ values and $\mathrm{CA}$ of the life-form categories). The invasion was analyzed together with the effect of stands (as explanatory variables).

The tests and the diagrams were performed by SigmaPlot 12.0 (Systat software, INC., San Jose, CA, USA).

\section{Results}

The frequency of species was analyzed in the different vegetation states (seminatural and natural) to detect the invasion impact on vegetation cover. Species frequency was higher in the three invaded stands (I2, I3 and I4) and was lower in two cases (I1 and I5) (Table 1). The frequency of Asclepias indicated the degree of the invasion, which was high compared to the frequency of annuals and perennials (Table 1). Interestingly, the highest frequency value of Asclepias was found in the invaded natural stand (I5). The three main lifeforms were analyzed in order to detect the possible effects of invasion. No significant differences were observed between the sites and invasion in the case of the frequency of the annuals and perennials. The frequency of cryptogams was lower in two invaded stands (I1 and I5) and higher in two other cases (I2; I3) (Table 1).

The CD and NRC functions were applied to the examination of species coexistence at the level of sites and invasion (Fig. 2, Table 2, Table S3 and Table S4). The maximum CD values did not differ significantly either in sites or in invasion (Fig. 2, Table 2). No significant difference was observed between sites in the CA of CD (Table 2). However, the CA of $\mathrm{CD}$ was significantly lower in the case of the invasion (Fig. 2 and Table 2) therefore, the maximum spatial diversity of species combinations was reached at a smaller spatial scale $\left(25-35 \mathrm{~cm}^{2}\right)$ by non-invaded stands. Contrariwise, the characteristic areas of the invaded stands were reached at larger scale, namely at $40-45 \mathrm{~cm}^{2}$.

The analysis of the maximum NRC values and CA of the stands did not demonstrate any significant difference either in sites or in invasion (Table 2).

In order to express the degree of disturbances, the stands were ranked by decreasing maximum $C D$ values. The invaded stands are located at the two ends of the disturbance scale, while the non-invaded ones are at the middle of the disturbance scale (Table S4).

The effects of invasion were tested on the three main life-form categories (annuals, perennials and cryptogams) by compositional diversity. However, the maximum $\mathrm{CD}$ values and the CA of the three main life-forms did not show significant differences in the comparison of the sites and invasion (Table S2).

\section{Discussion}

This study examined by microcoenological methods whether invasion impact is associated with decreasing beta diversity. We wanted to answer how invasion was affected by the initial stage of vegetation succession in open sand grassland. Based on the results, the species frequencies did 
Table 2. The maximum $\mathrm{CD}$ and NRC values and characteristic areas in $\mathrm{cm}^{2}(\mathrm{CA})$ where the functions reach their maximum. $\mathrm{SN}-\mathrm{semi-}$ natural sites (1-4), N - natural site (5), NI - non-invaded stands, I - invaded stands. Significance at $\mathrm{p}<0.05: *, \mathrm{p}<0.01: * *, \mathrm{p}<0.001$ : *** and non significant: ns. Species with an abundance below $2 \%$ are not included in the analysis.

\begin{tabular}{lccccclcc}
\hline $\begin{array}{c}\text { JNP- } \\
\text { function }\end{array}$ & Sites & $\begin{array}{c}\text { NI } \\
\text { (max. value) }\end{array}$ & I (max. value) & $\begin{array}{c}\text { NI } \\
(\mathrm{CA})\end{array}$ & $\begin{array}{c}\text { I } \\
(\mathrm{CA})\end{array}$ & $\begin{array}{c}\text { Comparison } \\
\text { (for two-way ANOVA) }\end{array}$ & $\begin{array}{c}\text { two-way ANOVA } \\
(p)\end{array}$ \\
\hline CD & SN & 6.417 & 7.550 & 35 & 45 & Site (max. values) & 0.557 & $\mathrm{~ns}$ \\
& $\mathrm{SN}$ & 5.611 & 5.372 & 35 & 45 & Invasion (max. values) & 0.497 & $\mathrm{~ns}$ \\
& $\mathrm{SN}$ & 6.834 & 7.355 & 25 & 45 & Site (CA) & 0.279 & $\mathrm{~ns}$ \\
& $\mathrm{SN}$ & 6.526 & 5.489 & 35 & 65 & Invasion (CA) & 0.009 & $* *$ \\
& $\mathrm{~N}$ & 7.115 & 3.947 & 35 & 60 & & & \\
\hline NRC & $\mathrm{SN}$ & 113 & 139 & 20 & 25 & Site (max. values) & 0.300 & $\mathrm{~ns}$ \\
& $\mathrm{SN}$ & 059 & 51 & 20 & 30 & Invasion (max. values) & 0.506 & $\mathrm{~ns}$ \\
& $\mathrm{SN}$ & 108 & 141 & 20 & 30 & Site (CA) & 0.990 & $\mathrm{~ns}$ \\
& $\mathrm{SN}$ & 82 & 42 & 20 & 30 & Invasion (CA) & 0.456 & $\mathrm{~ns}$ \\
\hline \hline
\end{tabular}
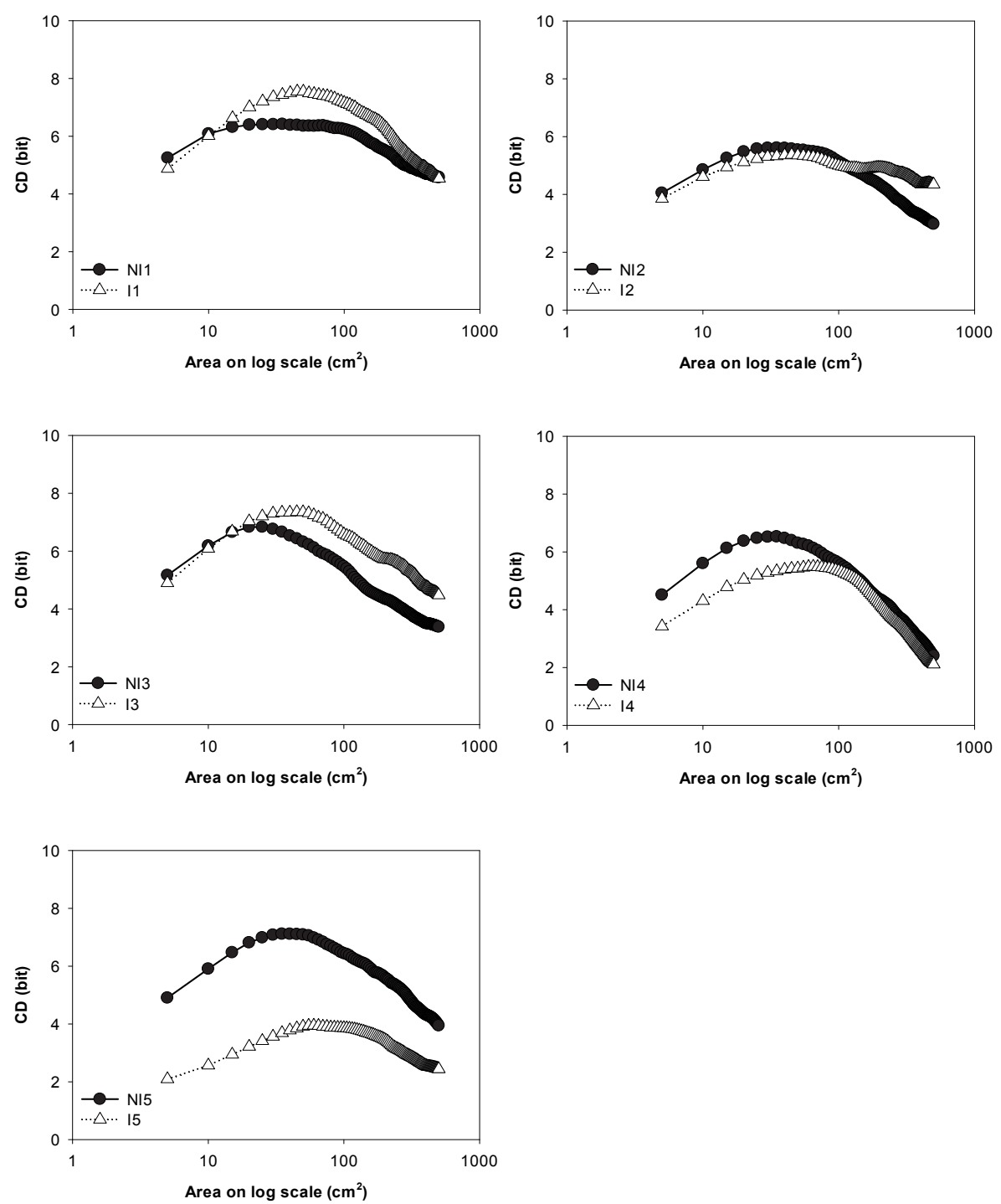

Figure 2. Compositional diversity of five stand-pairs as a function of increasing spatial scale. Species with abundance below $2 \%$ are not included in the analysis. Abbreviations: $\mathrm{SN}$ - seminatural sites (1-4), N - natural site (5), NI - non-invaded stands, I - invaded stands. 
not show any consistent change in the presence of Asclepias in every stand. However, the frequency of milkweed showed that the invasion was rather widespread in the invaded stands, regardless of the sites.

Some invasion studies (Szentes et al. 2012, Kun et al. 2014) have found that the maximum $C D$ and NRC values were lower and the CAs were typically higher during invasion, thus the invaded vegetation is less organized. Similar patterns can be detected in other degradation processes (Juhász-Nagy 1980, Juhász-Nagy and Podani 1983, JuhászNagy 1993, Horváth and Makrai 2000, Kovács-Láng et al. 2000, Bartha 2008, Bartha et al. 2008, Virágh et al. 2008, Bartha et al. 2011). The lower maximum values (CD or NRC) show a decrease of fine-scale structural complexity. While the higher characteristic areas of CD and NRC values can be interpreted that species are increasingly competing for space (Virágh et al. 2008). The CA shifts towards higher spatialscales indicate a slight but consistent changes in community structure toward degradation (in line with Virágh et al. 2008 and Bartha et al. 2011). This study shows that only the CA of compositional diversity was significantly higher in the invaded stands, compared to non-invaded ones. Thus, invasion has influenced the pattern of beta diversity, which is a kind of impoverishment of the community. Beta diversity in the invaded stands reached similar values to non-invaded stands but only at coarser scale. Methodologically, this main result pointed out that the maximum of $\mathrm{CA}$ of the $\mathrm{CD}$ was more sensitive and robust than the maximum CA of the NRC. Also this shows clearly the relevance of using the JNP method, i.e., these results support the application of the methodology to detect fine-scale vegetation changes.

Similarly to the results based on particular life-form frequencies, the $\mathrm{CD}$ of life-forms did not differ significantly (Table S2). The reason for the lack of the significance of the $\mathrm{CD}$ of the life forms could be that these life-forms grow together and therefore affect each other. So in the analyses, the effects of Asclepias and the other life-forms probably were confounded and could not be separated in a snapshot analysis.

Our study partly supported the previous findings about the correlation between invasion success and the state of recipient vegetation (initial degree of degradation in the recipient community) (Kneitel and Perrault 2006, Virágh et al. 2008, Szentes et al. 2012) (cf. Bartha et al. 2011) (Table S4). The non-invaded stands are more unified and they are wedged among the invaded ones. The highest difference of $C D$ values based on the analyzed JNP-functions was observed in the case of NI5-I5. It seems to be a contradiction because this stand-pair was located in the natural site. The highest difference may result from former disturbance (e.g., physical disturbance or drought effect), which created an appropriate situation for the invasion. The NI5-I5 stand-pair is a good example that Asclepias can penetrate from disturbed areas to natural places (Csontos et al. 2009, Csecserits et al. 2011, Albert et al. 2014, Szitár et al. 2014) but it is less typical and the invasion process may slow down if surrounded by nondisturbed habitats. There are no major differences between the other stand-pairs, because all of them were in the seminatural site (in disturbed condition). The most similar is the
NI2-I2 stand-pair, serious differences could not be detected between the invaded and non-invaded stands. Both of them had lower CD values, which is the feature of poorly organized, early stages of succession (Bartha 1990). The highest $\mathrm{CD}$ was found in the natural, undisturbed stand. If we assume that this non-invaded invaded pair had similarly high CD value at the time of first invasion impact, we can conclude that initially high $\mathrm{CD}$ did not increase the resistence to invasion in this vegetation type. However, this finding needs further tests because our study is limited by the low number of replicates and by the single survey. Moderate differences are detectable in three stand pairs (NI1-I1; NI3-I3 and NI4-I4). The most threatened non-invaded stand is NI1, which shows a rather disturbed condition. The other non-invaded stands (NI3 and NI4) were relatively safe. This is supported by Albert et al. (2014): milkweed cover increased significantly with decreased field age (time passed after the outset of disturbance) in the Kiskunság old-fields. It is reasonable to expect that CA values were shifted during invasion. Similarly, we can expect that after longer time and more invasion impact, the maximum $\mathrm{CD}$ values will decrease as well. This would be consistent with the fact that different plant communities resist differently to plant invasion (Vitousek et al. 1997, Alpert et al. 2000). The decreased spatial heterogeneity probably decreased the resilience (McNaughton 1988, Gunderson and Pritchard 2002, Bartha et al. 2011). These results can explain why Kelemen et al. (2016) found negative effect in the oldfields and why milkweed creates a novel ecosystem in open sand grasslands (in sandy old-fields). Szitár et al. (2016, 2018) found a ,positive” effect of milkweed, when milkweed created favorable microclimatic conditions for native species by shading. Both phenomena could also be explained by the clonality of common milkweed: deeply penetrating plagiotropic roots can reach the ground-water and this can be translocated by clonal system and released into upper soil layers where they were later used as neighbor plants, as demonstrated by Ye et al. (2016) in the case of other clonal species. Clonal plants can maintain the spatial pattern and inhibit the regeneration of vegetation after disturbance or modify the successional process (Oborny and Bartha 1995, 1998). So it is not surprising that the most dangerous invasive species are often clonal plants (Pyšek 1997, Kolar and Lodge 2001, Liu et al. 2006, Speek et al. 2011).

The results of this comparative microcoenological study suggest that invasion by Asclepias occurs more often in previously disturbed habitats and less typical in the natural ones. $A$. syriaca could invade and reach a larger population where the community was already disturbed. This study is based on single time point observations, but it requires further (long-term) studies to clarify these questions. It is worth mentioning from the invasion management point of view, that protection of the habitats against disturbance is a more cost-effective and successful way than the protection against the establishment or extirpation of invasive species, since disturbance facilitates invasion throughout the impoverishment of the community.

Acknowledgements: I acknowledge the general support of the Kiskunság National Park Directors to authorize this field 
work in the strictly protected area. I gratefully thank for corrections of valuable comments of Á. Szepesi and I. Bagi from Department of Plant Biology, University of Szeged and two anonymous reviewers, who helped me to improve the manuscript. I am very grateful for the help and suggestion of A. Horvath in the application of the INFOTHEM 3.01 program. Last but not least I would like to thank for the assistance during the field work to E. Dóri.

\section{References}

Addicott, E., S. Laurance, M. Lyons, D. Butler and J. Neldner. 2018 When rare species are not important: linking plot-based vegetation classifications and landscape-scale mapping in Australian savanna vegetation. Community Ecol. 19:67-76.

Albert, Á.J., A. Kelemen, O. Valkó, T. Miglécz, A. Csecserits, T. Rédei, B. Deák, B. Tóthmérész and P. Török. 2014. Secondary succession in sandy old-fields: a promising example of spontaneous grassland recovery. App. Veg. Sci. 17:214-224.

Alpert, P., E. Bone and C. Holzapfel. 2000. Invasiveness, invasibility and the role of environmental stress in the spread of non-native plants. Perspect. Plant Ecol. Evol. Syst. 3:52-66.

Bagi, I. 2008. Common milkweed (Asclepias syriaca L.). In: BottaDukát, Z. and L. Balogh. (eds.), The Most Important Invasive Plants in Hungary. Institute of Ecology and Botany. H.A.S. Vácrátót. pp. 151-159.

Bagi, I. and Z. Szilágyi. 1995. Az Asclepias syriaca cönológiai viszonyai a Kiskunsági Nemzeti Park fokozottan védett homokterületein. Bot. Közlem. 82:147. (in Hungarian).

Bartha, S. 1990. Spatial processes in developing plant communities: pattern formation detected using information theory. In: Krahulec F., A.D.Q. Agnew, S. Agnew and J. Willems. (eds.), Spatial Processes in Plant Communities. Academia and SPB Publ., Prague and The Hague. pp. 31-48.

Bartha, S. 2008. Mikrocönológiai módszerek a táji vegetáció állapotának vizsgálatára.(New methods of fine-resolution vegetation analyses applicable for landscape-scale surveys and monitoring.). Tájökológiai Lapok 6:229-245. (in Hungarian, with English abstract)

Bartha, S., G. Campetella, E. Ruprecht, A. Kun, J. Házi, A. Horváth, K. Virágh and Zs. Molnár. 2008. Will interannual variability in sand grassland communities increase with climate change? Community Ecol. 9 (Supplement 1):13-21.

Bartha, S., G. Campetella, M. Kertész, I. Hahn, Gy. Kröel-Dulay, T. Rédei, A. Kun, K. Virágh, G. Fekete and E. Kovács-Láng. 2011 Beta diversity and community differentiation in dry perennial sand grasslans. Ann. Bot. 2011:9-18.

Bartha, S., T. Czárán and J. Podani. 1998. Exploring plant community dynamics in abstract coenostate spaces. Abstr. Bot. 22:49-66.

Bartha, S. and M. Kertész. 1998. The importance of neutral-models in detecting interspecific spatial associations from 'trainsect'data. Tiscia 31:85-98.

Botta-Dukát, Z. 2005. The relationship between Juhász-Nagy’s information theory functions and the log-linear contingency table analysis. Acta Bot. Hung. 47:53-73.

Botta-Dukát, Z. 2008. Invasion of alien species to Hungarian (semi-) natural habitats. Acta Bot. Hung. 50:219-227.

Campetella, G. and R. Canullo. 2001. Structure and spatial scale in woodland vegetation studies in permanent plots: a determinant feature of monitoring. ISAFA, 2001/02. 101-111. (in Italian, with English abstract)
Campetella, G., R. Canullo and D. Bartha. 1999. Fine scale spatial pattern analysis of herb layer of woodland vegetation using information theory. Plant Biosystems 133:277-288.

Csecserits, A., B. Czúcz, M. Halassy, G. Kröel-Dulay, T. Rédei, R. Szabó, K. Szitár and K. Török. 2011. Regeneration of sandy oldfields in the forest steppe region of Hungary. Plant Biosystems 145:715-729.

Csontos, P., E. Bózsing, I. Cseresnyés and K. Penksza. 2009 Reproductive potential of the alien species Asclepias syriaca (Asclepiadaceae) in the rural landscape. Pol. J. Ecol. 57:383388.

Elton, C.S. 1958. The Ecology of Invasions by Animals and Plants. Methuen, London, UK.

European Commissions. 2014. Regulation (EU) No 1143/2014 of the European Parliament and of the Council October 222014 on the prevention and management of the introduction and spread of invasive alien species. Official Journal of the European Union L174:5-11, https:/publications.europa.eu/en/publication-detail/ -/publication/880597b7-63f6-11e4-9cbe-01aa75ed71a1/language-en

European Commissions. 2017. List of Invasive Alien Species of Union concern. http://ec.europa.eu/environment/nature/invasivealien/list/index en.htm

Fekete, G., Z. Molnár, E. Magyari, I. Somodi and Z. Varga. 2014 A new framework for understanding Pannonian vegetation patterns: regularities, deviations and uniqueness. Community Ecol. $15: 12-26$.

Gallé, R., N. Erdélyi, N. Szpisjak, C. Tölgyesi and I. Maák. 2015. The effect of the invasive Asclepias syriaca on the grounddwelling arthropod fauna. Biologia 70:104-112.

Gunderson, L.H. and Jr.L. Pritchard. (eds.) 2002. Resilience and the Behaviour of Large-Scale Systems. Island Press, Washington.

Hierro, J.L., D. Villarreal, Ö. Eren, J. M. Graham and R.M. Callaway. 2006. Disturbance facilitates invasion: the effects are stronger abroad than at home. Am. Nat. 168:144-156.

Hobbs, R.J. 1989. The nature and effects of disturbance relative to invasions. In: Drake, J. A., H. A. Mooney, F. Di Castri, R. H. Groves, F. J. Kruger, M. Rejmanek and M. Williamson. (eds.), Biological Invasions: A Global Perspective. John Wiley and Sons, New York. pp. 389-405.

Horváth, A. 1998. INFOTHEM program: new possibilities of spatial series analysis based on information theory methods. Tiscia 31:71-84.

Horváth, A. and L. Makrai. 2000. Variability of spatial dependence within a pioneer plant community. Tiscia 32:19-29.

Juhász-Nagy, P. 1980. Modelling of coexistential structures in coenology. Academic Doctoral Thesis, MTA, Budapest. 238 p. (in Hungarian).

Juhász-Nagy, P. 1993. Notes on compositional diversity. Hydrobiologia 249:173-182.

Juhász-Nagy, P. and J. Podani. 1983. Information theory methods for the study of spatial processes and succession. Vegetatio 51:129140 .

Kazinczi, G., I. Béres, J. Mikulás and E. Nádasy. 2004. Allelopathic effect of Cirsium arvense and Asclepias syriaca. Z. Pfl. Krankh. Pfl. Schutz Sonderh. 19:301-308.

Kelemen, A., O. Valkó, G. Kröel-Dulay, B. Deák, P. Török, K. Tóth, T. Miglécz and B. Tóthmérész. 2016. The invasion of common milkweed (Asclepias syriaca) in sandy old-fields-is it a threat to the native flora? App. Veg. Sci. 19:218-224. 
Király, G. (ed.) 2009. Új magyar füvészkönyv. Magyarország hajtásos növényei. Aggtelek Nemzeti Park Igazgatóság, Jósvafö. (in Hungarian).

Kneitel, J. and D. Perrault. 2006. Disturbance-induced changes in community composition increase species invasion success. Community Ecol. 7:245-252.

Kolar, C.S., D.M. Lodge. 2001. Progress in invasion biology: predicting invaders. Trends Ecol. Evol. 16:199-204

Kovács-Láng, E., G. Kröel-Dulay, M. Kertész, G. Fekete, S. Bartha, J. Mika, T. Rédei, K. Rajkai and I. Hahn. 2000. Changes in the composition of sand grasslands along a climatic gradient in Hungary and implications for climate change. Phytocoenologia 30:385-407.

Kun, A. 2001. Analysis of precipitation year and their regional frequency distributions in the Danube-Tisza mid-region, Hungary. Acta Bot. Hung. 43:175-187.

Kun, R., M. Szépligeti, Á. Malatinszky, K. Virágh, I. Szentirmai and S. Bartha. 2014. Egy inváziós faj, a Solidago gigantea Aiton által kolonizált mocsárrétek diverzitása és fajkompozíciós koordináltsága. (Changing diversity and coenological coordination in marshmeadows colonised by the invasive Solidago gigantea Aiton.) Bot. Közlem. 101:65-78. (in Hungarian, with English abstract).

Lembrechts, J.J., A. Pauchard, J. Lenoir, M.A. Nuñez, C. Geron, A. Ven, P. Bravo-Monasterio, E. Teneb, I. Nijs and A. Milbau. 2016. Disturbance is the key to plant invasions in cold environments. PNAS 113:14061-14066.

Liu, J., M. Dong, S.L. Miao, Z.Y. Li, M.H. Song and R.Q. Wang. 2006. Invasive alien plants in China: role of clonality and geographical origin. Biol. Invasions 8:1461-1470.

Lökös, L. and P. K. Verseghy. 2001. The lichen flora of the Kiskunság National Park and the southern part of the Danube-Tisza Interfluve. In: Lökös, L. and M. Rajczy. (eds.), The Flora of the Kiskunság National Park. Vol. 2. Cryptogams. Hungarian Natural History Museum, Budapest. pp. 299-362.

Magyari, E.K., J.C. Chapman, D.G. Passmore, J.R.M. Allen, J.P. Huntley and B. Huntley. 2010. Holocene persistence of wooded steppe in the Great Hungarian Plain. J. Biogeogr. 37:915-935.

McNaughton, S.J. 1988. Diversity and stability. Nature 333:204-205.

Mojzes, A. and T. Kalapos. 2015. Plant-derived smoke enhances germination of the invasive common milkweed (Asclepias syriaca L.). Pol. J. Ecol. 63:280-285.

Molnár, Z. (ed.) 2003. A Kiskunság száraz homoki növényzete (Sanddunes in Hungary, Kiskunság). TermészetBÚVÁR Alapítvány Kiadó, Budapest. 68 pp. (in Hungarian).

Molnár, Z. and A. Kun. (eds.) 2011. Magyarország élöhelyei: vegetációtipusok leirása és határozója: ÁNÉR 2011. MTA Ökológiai és Botanikai Kutatóintézete. (in Hungarian).

Oborny, B. and S. Bartha. 1995. Clonality in plant communities - an overview. Abstr. Bot. 115-127.

Oborny, B. and S. Bartha. 1998. Formakincs és közösségszervezõdés a növénytársulásokban: a klonális növények szerepe. In: Fekete, G. (ed.), A közösségi ökológia frontvonalai. Scientia, Budapest. pp. 59-86. (in Hungarian)

Pyšek, P. 1997. Clonality and plant invasion: can a trait make a difference? In: de Kroon, H., J. Groenendael. (eds.), The Ecology and Evolution of Clonal Plants. Backhuys Publishers, Leiden. pp. 405-427

Pyšek, P., M. Chytrý, J. Pergl, J. Sádlo and J. Wild. 2012. Plant invasions in the Czech Republic: current state, introduction dynamics, invasive species and invaded habitats. Preslia 84:575-629.
Pyšek, P., M. Chytrý, J. Pergl, J. Sádlo and J. Wild. 2017. Plant Invasions in the Czech Republic. In: Chytrý, M., J. Danihelka, Z. Kaplan, P. Pyšek. (eds.), Flora and Vegetation of the Czech Republic. Plant and Vegetation, vol 14. Springer, Cham. pp. 339399.

Rédei, T., K. Szitár, B. Czúcz, S. Barabás, E. Lellei-Kovács, I. Pándi, L. Somay and A. Csecserits. 2014. Weak evidence of long-term extinction debt in Pannonian dry sand grasslands. Agric. Ecosyst. Environ. 182:137-143.

Sala, O.E., F.S. Chapin, J.J. Armesto, E. Berlow, J. Bloomfield, R. Dirzo, E. Huber-Sanwald, L.F. Huenneke, R.B. Jackson, A. Kinzig, R. Leemans, D.M. Lodge, H.A. Mooney, M. Oesterheld, N. LeRoy Poff, M. T. Sykes, B.H. Walker, M. Walker and D.H. Wall. 2000. Global biodiversity scenarios for the year 2100 . Science 287:1770-1774.

Somogyi, A.Á., G. Lőrinczi, J. Kovács and I.E. Maák. 2017. Structure of ant assemblages in planted poplar (Populus alba) forests and the effect of the common milkweed (Asclepias syriaca). Acta Zool. Acad. Sci. Hung. 63:443-457.

Speek, T.A., L.A. Lotz, W.A. Ozinga, W.L. Tamis, J.H. Schaminée and W.H. van der Putten. 2011. Factors relating to regional and local success of exotic plant species in their new range. Divers. Distrib. 17:542-551.

Szatmári, J., Z. Tobak and Z. Novák. 2016. Environmental monitoring supported by aerial photography-a case study of the burnt down Bugac juniper forest, Hungary. J. Environ. Geog. 9:31-38.

Szentes, S., Z. Sutyinszki, G. Szabó, Z. Zimmermann, J. Házi, B. Wichmann, L. Hunfnágel, K. Penksza and S. Bartha. 2012. Grazed Pannonian grassland beta-diversity changes due to $\mathrm{C} 4$ yellow bluestem. Cent. Eur. J. Biol. 7:1055-1065.

Szigetvári, C. 2002. Az invazív késeiperje, Cleistogenes serotina (L.) Keng. szerepe nyílt homokgyepek társulásszerveződésében. (The role of the invasive Cleistogenes serotina (L.) Keng. in community organization of open sand grassland communities.) Kitaibelia 2:119-139. (in Hungarian, with English abstract)

Szitár, K., G. Kröel-Dulay and K. Török. 2018. Invasive Asclepias syriaca can have facilitative effects on native grass establishment in a water-stressed ecosystem. Appl. Veg. Sci. 21:607-614.

Szitár, K., G. Ónodi, L. Somay, I. Pándi, P. Kucs and G. Kröel-Dulay. 2014. Recovery of inland sand dune grasslands following the removal of alien pine plantation. Biol. Conserv. 171:52-60.

Szitár, K., G. Ónodi, L. Somay, I. Pándi, P. Kucs and G. Kröel-Dulay. 2016. Contrasting effects of land use legacies on grassland restoration in burnt pine plantations. Biol. Conserv. 201:356-362.

Tokarska-Guzik, B. and E. Pisarczyk. 2015. Risk Assessment of Asclepias syriaca. https://www.codeplantesenvahissantes.fr/ fileadmin/PEE_Ressources/TELECHARGEMENT/Asclepias_ syriaca_RA.pdf

Tóth, K. (ed.) 1996. 20 éves a Kiskunsági Nemzeti Park 1975-1995. Kiskunság Nemzeti Park Igazgatósága, Kecskemét. 234 pp. (in Hungarian with English abstracts).

Tóthmérész, B. and Z. Erdei. 1992. The effect of species dominance on information theory characteristics of plant communities. Abstr. Bot. 16:43-47.

Török, K, Z. Botta-Dukát, I. Dancza, I. Németh, J. Kiss, B. Mihály and D. Magyar. 2003. Invasion gateways and corridors in the Carpathian Basin: biological invasions in Hungary. Biol. Invasions 5:349-356.

Várallyay, G. 1993. Soils in the region between the rivers Danube and Tisza (Hungary). In: Szujkó-Lacza, J. and D. Kováts. (eds.), The Flora of the Kiskunság National Park. Magyar Természettudományi Múzeum, Budapest. pp. 21-42. 
Veres, K. and Z. Csintalan. 2017. Life on sand dunes from lichens point of view-effect of microclimate and seasonality on activity of terricolous lichen communities. Acta Biol. Plant. Agriensis 5: $62-62$.

Virágh, K., A. Horváth, S. Bartha and I. Somodi. 2008. A multiscale methodological approach for monitoring the effectiveness of grassland management. Community Ecol. 9:237-246.

Vitousek, P.M., C.M. D’Antonio, L.L. Loope, M. Rejmánek and R. Westbrooks. 1997. Introduced species: a significant component of human-caused global change. NZ J. Ecol. 21:1-16.

Weidenhamer, J.D. and R.D. Callaway. 2010. Direct and indirect effects of invasive plants on soil chemistry and ecosystem function. J. Cem. Ecol. 36:59-69.

Ye, X. H., Y. L. Zhang, Z. L. Liu, S. Q. Gao, Y. B. Song, F. H. Liu and M. Dong. 2016. Plant clonal integration mediates the horizontal redistribution of soil resources, benefiting neighboring plants. Front. Plant Sci. 7:77.

Zsákovics, G., F. Kovács, A. Kiss and E. Pócsik. 2007. Risk analysis of the aridification-endangered sand-ridge area in the DanubeTisza Interfluve. Acta Climatol. Chorol. Univ. Szeged. 40:169178.

Zsákovics, G., F. Kovács and A. Kiss. 2009. Complex analysis of an aridification-endangered area: case study from the Danube-Tisza Interfluve. Tájökológiai Lapok 7:117-126.

Received September 4, 2018

Revised December 17, 2018, January 5, 2019

Accepted February 1, 2019

\section{Supplementary material}

Table S1. GPS coordinates of the five stand-pairs.

Table S2. Maximum CD values and characteristic areas (CA) of the three life-forms and those two-way ANOVA test.

Table S3. Results of the complete randomization (the average of the Monte-Carlo simulations and its significance tests).

Table S4. The quantification of degree of disturbances for each stands (where the decreasing max. CD values indicate the degree of disturbances).

The appendix may be downloaded from www.akademiai. com.

Open Access statement. This is an open-access article distributed under the terms of the Creative Commons Attribution 4.0 International License (https://creativecommons.org/ licenses/by/4.0/), which permits unrestricted use, distribution, and reproduction in any medium, provided the original author and source are credited, a link to the CC License is provided, and changes - if any - are indicated. (SID_1). 